\author{
NANAEKE \\ Indonesian Journal of Early Childhood Education \\ Volume 3, Nomor 1, Juni 2020
}

\title{
CAPAIAN DAN STIMULASI ASPEK PERKEMBANGAN SENI PADA ANAK KEMBAR USIA 5 TAHUN
}

\author{
Eka Damayanti \\ Jurusan Pendidikan Islam Anak Usia Dini \\ Fakultas Tarbiyah dan Keguruan, UIN Alauddin Makassar \\ E-mail: eka.damayanti@uin-alauddin.ac.id \\ Andi Rezeky Amaliah \\ Jurusan Pendidikan Islam Anak Usia Dini \\ Fakultas Tarbiyah dan Keguruan, UIN Alauddin Makassar \\ E-mail: a.rezekyamaliah24@gmail.com \\ Ismawati \\ Jurusan Pendidikan Islam Anak Usia Dini \\ Fakultas Tarbiyah dan Keguruan, UIN Alauddin Makassar \\ E-mail: 20900116030@uin-alauddin.ac.id
}

\begin{abstract}
Abstrak
Penelitian ini bertujuan untuk mengetahui gambaran perkembangan seni pada anak kembar usia 5 tahun berdasarkan Standar Tingkat Pencapaian Perkembangan Anak dan merumuskan stimulasi yang tepat. Penelitian dilakukan menggunakan pendekatan kualitatif jenis studi kasus. Subjek penelitian sebanyak dua anak kembar yang berusia 5 tahun. Pengumpulan data menggunakan teknik observasi dan wawancara dengan menggunakan pedoman observasi dan wawancara. Data dianalisis menggunakan narasi deskriptif. Hasil penelitian menunjukkan kedua anak telah memenuhi capaian perkembangan pada aspek seni anak berdasarkan standar usia 5 tahun, khususnya dalam hal menikmati berbagai alunan lagu atau suara yang dibuktikan dengan kemampuan: (1) bersenandung atau bernyanyi sambil mengerjakan sesuatu; (2) memainkan alat musik/instrument/benda bersama teman. Anak juga telah tertarik dengan kegiatan seni yang dibuktikan dengan kemampuan: (1) menyanyikan lagu dengan sikap yang benar; (2) menggunakan berbagai macam alat musik; (3) bermain drama sederhana; (4) menggambar berbagai macam bentuk yang beragam; (5) melukis dengan berbagai cara dan objek; (6) membuat karya seperti bentuk sesungguhnya dengan berbagai bahan. Berdasarkan hasil penelitian, ada beberapa stimulasi yang dapat diterapkan untuk meningkatkan capaian aspek perkembangan seni pada anak usia 5 tahun, yakni: (1) mendukung minat anak dan memperdengarkan anak lagu-lagu yang disukainya; (2) memberikan apresiasi berbentuk pujian pada anak; (3) memberikan fasilitas berupa beberapa alat permainan yang dapat mengembangkan aspek seni anak; dan (4) apabila anak berhasil melakukan hal positif, maka anak diberikan reward.
\end{abstract}

Kata Kunci: Anak Kembar, Aspek Perkembangan Seni, Stimulasi 


\begin{abstract}
This study aims to recognize the child mental art development art of 5 years old twins based on the Standards of Achievement in Child Development and to formulate appropriate stimulation for child. The study was conducted using a qualitative approach with case study type. The subjects of the study were 5 years of two twins brothers. Data collection used observation and interview techniques. Data were analyzed using descriptive narrative. The results shows the two children had fulfilled the developmental achievements in the aspect of children's art based on the standard age of 5 years, especially in terms of enjoying a variety of songs or sounds as evidenced by the ability: (1) humming or singing while doing something; (2) playing a musical instrument, instrumental object with their friends. Children have also been interested in art activities as evidenced by the ability to: (1) sing songs with the right attitude; (2) using a variety of musical instruments; (3) playing a simple drama; (4) drawing a variety of diverse shapes; (5) painting in various ways and objects; (6) making works like the actual form with various materials. Based on the results of the study, there are several stimulations could be applied to improve the achievement of art development in children aged 5 years, namely: (1) supporting the interests of children and playing their favorite songs; (2) giving appreciation in the form of praise to children; (3) providing facilities in the form of several playing instruments that can develop aspects of children's art; and (4) giving reward to children of succeeded doing positive things.

Keywords:
\end{abstract}

Keywords: Aspects of Art Development, Stimulation, Twins

\title{
PENDAHULUAN
}

Anak usia dini merupakan anak yang berada pada rentang usia 0-6 tahun atau disebut dengan masa keemasan "golden age". Menurut Fadillah (2012) pada usia ini anak lebih mudah untuk meniru semua hal yang dilihatnya dari hasil skematanya sendiri. Menurut Khairi (2018) yang mengatakan bahwa anak usia dini adalah individu yang sedang mengalami proses pertumbuhan dan perkembangan yang sangat pesat, bahkan dikatakan sebagai lompatan perkembangan. Anak usia dini memiliki rentang usia yang sangat berharga dibanding dengan usia-usia selanjutnya karena perkembangan kecerdasannya sangat luar biasa. Usia tersebut merupakan fase kehidupan yang unik dan berada pada masa proses perubahan berupa pertumbuhan, perkembangan, pematangan, dan penyempurnaan baik pada aspek jasmani maupun rohaninya yang berlangsung seumur hidup, bertahap dan berkesinambungan. Menurut Nurmalitasari (2015) anak usia dini adalah seorang anak yang usianya belum memasuki lembaga formal seperti sekolah dasar dan biasanya mereka tetap tinggal di rumah atau mengikuti kegiatan dalam bentuk berbagai lembaga pendidikan pra-sekolah, seperti kelompok bermain, taman kanak-kanak, atau taman penitipan anak.

2 NANAEKE - Indonesian Journal of Early Childhood Education, Vol. 3, No. 1, Juni 2020 
Pendidikan anak usia dini merupakan salah satu pendidikan yang penting untuk dilalui dalam kehidupan individu pada usia dini, karena kesempatan itu hanya hadir satu kali selama rentang kehidupan manusia. Pendidikan anak usia dini dapat dilaksanakan melalui tiga jalur, yaitu jalur informal yang dilaksanakan dalam keluarga, jalur formal yang dilaksanakan pada taman kanak-kanak atau raudhatul athfal dan jalur non formal yang dilaksanakan melalui posyandu dan penitipan anak (Khaironi, 2017). Menurut The National for the Educational of Young Children (NAEYC) merumuskan mengenai pendidikan anak usia dini bahwa pendidikan yang melayani anak usia dini sejak umur 0-6 tahun dengan melakukan kegiatan kurang dari seharian penuh atau bahkan seharian penuh, baik dilakukan di lingkungan rumah maupun institusional (Seefeldt; (Indrijati, 2016). Pendidikan anak usia dini merupakan suatu upaya pembinaan dalam memberikan rangsangan guna mengembangkan pertumbuhan dan perkembangan rohani dan jasmani anak sehingga mempunyai kesiapan untuk memasuki tahapan pendidikan selanjutnya (Fiah, 2017). Dalam Peraturan Pemerintah Nomor 19 Tahun 2005 tentang Standar Pendidikan Nasional Pasal 19 ayat 1 yang menegaskan bahwa "Proses pembelajaran pada satuan pendidikan diselenggarakan secara interaktif, inspiratif, menyenangkan, menantang, memotivasi peserta didik untuk berpartisipasi aktif serta memberikan ruang yang cukup bagi prakarsa, kreativitas, dan kemandirian sesuai dengan bakat, minat, dan perkembangan fisik serta psikologis peserta didik". Menurut Munawaroh (2017) pendidikan anak usia dini lebih menitkberatkan pada peletakan dasar pertumbuhan dan perkembangan anak.

Pemberian stimulasi akan menjadi efektif jika orang tua atau pengasuh memberikan dan memperhatikan kebutuhan anak sesuai dengan tahapan perkembangan anak. Stimulasi merupakan suatu usaha memberikan sesuatu agar dapat menghasilkan apa yang diinginkan terhadap apa yang telah diberikan stimulasi (Satriana, 2013). Stimulasi perkembangan pada anak usia dini dilakukan dalam lingkup keluarga dan dalam lingkup pendidikan formal yang biasa dalam lembaga satuan Pendidikan Anak Usia Dini (PAUD). Lebih Ianjut Khadijah (2016) mengungkapkan stimulasi pada anak usia dini sangat penting dilakukan karena perkembangan anak usia dini tidak bisa diulang lagi. Stimulasi yang diberikan pada anak uisa dini dimasa sekarang akan berdampak pada kualitas anak dimasa depan.

Anak sangat memerlukan perhatian khusus dalam mengoptimalisasikan tumbuh kembangnya. Optimalisasi perkembangan diperlukan adanya interaksi anak dengan orang tua, yang sangat berperan adalah ibu yang mempunyai manfaat bagi tahapan perkembangan anak. Peran orang tua sangat penting, karena orangtua secara cepat dapat mengenali kelainan yang terjadi pada anaknya dan dapat mengatasinya dengan memberikan stimulasi yang tepat sedini mungkin. Ada beberapa faktor yang dapat mempengaruhi perkembangan anak yaitu stimulasi dini yang tidak kuat, anemia defisiensi besi, malnutrisi kronis berat, dan defisiensi 
yodium. Faktor resiko sangat penting dan mempunyai hubungan erat antara interaksi ibu dan anak yaitu pemberian stimulasi pada usia dini (Suryawan, 2012).

Aspek perkembangan seni merupakan salah satu aspek yang perlu dikembangankan pada anak usia dini, mendidik anak melalui seni, bukan hanya untuk anak yang berbakat saja melainkan seni untuk mengembangkan potensi diri dan menumbuhkan kreatif bagi anak (Sitepu, 2020). Menurut Kusumastuti (2004) perkembangan seni juga berpengaruh pada perkembangan anak khususnya pada perkembangan motorik kasar dan halus anak, pola bahasa dan pikir serta perkembangan sosial anak. Jazuli (2008) juga menyatakan bahwa seni dapat digunakan dalam mengembangkan potensi kreatif. Potensi ini dapat dilihat dari cara dalam berpikir kritis dan kemampuan dalam berpikir, rasa keingintahuan sangat tinggi, mampu mengekspresikan diri di muka umum, mampu mengemukakan ide dan pendapat yang orisinil, berani tampil beda dan berani mengambil resiko, mampu menerima pendapat orang lain, juga menghargai diri sendiri dan orang lain. Rohendi (2016) mengatakan bahwa seni merupakan salah satu aspek yang tidak bisa lepas dari kehidupan manusia dilihat dari perspektif manapun, kebanyakan orang beranggapan bahwa seni hanya yang dapat dilihat saja seperti kesenian dan lukisan.

Berdasarkan beberapa teori diatas, temuan dalam penelitian ini dapat bermanfaat sebagai panduan bagi orangtua dan guru dalam menstimulasi perkembangan seni anak. Kemampuan orangtua dalam menjalin interaksi dan komunikasi bersama anak serta lingkungan merupakan penentu tercapainya keberhasilan stimulus yang diberikan kepada anak.

\section{METODE PENELITIAN}

Penelitian ini menggunakan pendekatan kualitatif jenis studi kasus karena fokus pada kasus perkembangan seni subjek yang diamati. Subjek penelitian yaitu sepasang anak kembar (SR dan SY) yang berusia 5 tahun yang dipilih berdasarkan kriteria: (1) anak usia dini; (2) anak kembar; (3) mudah dijangkau oleh peneliti; (4) bersedia menjadi subjek penelitian. Lokasi penelitian dilakukan di dusun Tulekko, desa Bontomarannu, Kecamatan Bontotiro Kabupaten Bulukumba selama tiga bulan yakni bulan Maret - Mei 2020.

Data dikumpulkan menggunakan teknik observasi dan wawancara. Peneliti sebagai instrumen kunci menggunakan bantuan pedoman observasi dan wawancara yang disusun berdasarkan indikator tingkat pencapaian perkembangan berdasarkan tingkat pencapaian perkembangan anak dalam Peraturan Menteri Pendidikan dan Kebudayaan Republik Indonesia Nomor 137 Tahun 2014 Tentang Standar Nasional Pendidikan Anak Usia Dini, khususnya pada aspek perkembangan Seni anak usia 5 tahun. Pertama, mampu menikmati berbagai alunan lagu atau suara, ditandai dengan kemampuan yakni (1) anak bersenandung atau bernyanyi sambil mengerjakan sesuatu; (2) memainkan alat musik/

4 NANAEKE - Indonesian Journal of Early Childhood Education, Vol. 3, No. 1, Juni 2020 
instrument/ benda bersama teman. Kedua, Tertarik dengan kegiatan seni, ditandai dengan kemampuan yakni: (1) menyanyikan lagu dengan sikap yang benar; (2) menggunakan berbagai macam alat musik tradisional maupun alat musik lain untuk menirukan suatu irama atau lagu tertentu; (3) bermain drama sederhana; (4) menggambar berbagai macam bentuk yang beragam; (5) melukis dengan berbagai cara dan objek; (6) membuat karya seperti bentuk sesungguhnya dengan berbagai bahan (kertas, plastisin, balok, dll).

Data yang dikumpulkan selanjutnya dianalisis dengan cara menarasikan secara deskriptif dengan menggambarkan secara lengkap dan menyeluruh hasil observasi dan wawancara berdasarkan indikator tingkat pencapaian perkembangan seni anak. Untuk menjaga keabsahan data supaya hasil penelitian ini memenuhi standar derajat kepercayaan, maka peneliti lakukan: (1) Memperpanjang pengamatan, dilakukan dengan penelitian selama tiga bulan; (2) Ketekunan pengamatan, dilakukan dengan memperhatikan perbedaan secara detail tiap capaian perkembangan dan peneliti juga memberikan stimulus jika capaian perkembangan tidak muncul pada saat observasi dan wawancara dilakukan; (3) Triangulasi, dilakukan dengan membandingkan data dari hasil observasi dengan hingga data hasil wawancara, selain itu juga membandingkan temuan pada anak dengan hasil wawancara dari orang tua anak.

\section{HASIL PENELITIAN DAN PEMBAHASAN}

Hasil penelitian menunjukkan bahwa kedua subjek SR dan SY telah memenuhi standar tingkat pencapaian perkembangan seni anak usia 5 tahun. Hasilnya secara detail dapat digambarkan sebagai berikut:

\section{Mampu menikmati berbagai alunan lagu atau suara Bersenandung atau bernyanyi sambil mengerjakan sesuatu}

Berdasarkan hasil observasi dari indikator anak bersenandung atau bernyanyi sambil mengerjakan sesuatu didapatkan hasil bahwa kedua subjek sudah mampu menikmati alunan lagu. Anak bernyanyi saat mengerjakan sesuatu, terlihat ketika SR bermain (menjadi pedagang di pasar) saat menjajakan dagangannya SR sambil bernyanyi, dan ketika SR menggambar atau menulis sesuatu terkadang SR bersenandung menirukan lagu yang biasa dinyanyikan di sekolah seperti lagu Baby Shark. Begitupun dengan SY, saat mengerjakan sesuatu SY terkadang bersenandung walaupun hanya sepotong-sepotong. Ketika bernyanyi SR dan SY juga terlihat sangat percaya diri dan pengucapan artikulasi lagunya sangat jelas. Selain itu, SR dan SY juga sangat suka berhitung dikarenakan lagu kesukaannya yaitu lagu berhitung. Melalui kegiatan bernyanyi ini, SR dan SY menjadi hafal rukun islam, rukun iman, nama-nama malaikat dan nama-nama nabi.

\section{Memainkan alat musik/instrument/benda bersama teman}

Pada tingkatan ini, SY sudah mampu memainkan alat musik/instrument/ 
benda bersama teman terlihat ketika SY bermain band bersama teman, dengan memanfaatkan benda-benda seperti kardus tempat mainan sebagai drum, ember dijadikan sebagai gendang dan bermain piano mainan. Lain halnya dengan SR, saat bermain band bersama temannya SR lebih suka menjadi vokalis. Meskipun demikian SR sudah bisa memainkan pianika dengan "not" dasar, walaupun masih dibantu oleh gurunya di sekolah.

\section{Tertarik dengan kegiatan seni}

\section{Menyanyikan lagu dengan sikap yang benar}

Dari hasil pengamatan pada indikator tertarik dengan kegiatan seni, kedua subjek yakni SR dan SY sudah mampu menyanyikan lagu dengan sikap yang benar. Terlihat pada saat SR dan SY menyanyikan lagu yang gembira, ekspresi wajah yang sangat gembira dan tersenyum serta menggunakan gelas seolah-olah dijadikan sebagai mic. Ketika bernyanyi anak juga menunjukkan ekspresi yang benar dan sesuai dengan lirik lagu seperti pada saat menyanyikan lagu gembira anak tersenyum sambil menyanyikannya.

\section{Menggunakan berbagai macam alat musik tradisional maupun alat musik lain untuk menirukan suatu irama atau lagu tertentu}

SR dan SY belum bisa memainkan alat musik tradisional, karena tidak ada yang memfasilitasinya. Meskipun demikian SR sudah bisa memainkan alat musik untuk menirukan irama yaitu alat musik pianika di sekolah, meskipun hanya nada dasar do, re, mi, fa, so, la, si, do. Lain dengan SR yang belum bisa memainkan alat musik pianika akan tetapi SY terkadang menirukan irama atau lagu tertentu dengan menggunakan ember yang dijadikan sebagai gendang.

\section{Bermain drama sederhana}

Pada indikator bermain drama sederhana terlihat SR dan SY mampu bermain peran. Terlihat ketika SR dan SY bermain peran bersama seperti, saat main rumahrumahan SR berperan sebagai kakak dan SY berperan sebagai adik. Saat bermain dokter-dokteran SR berperan sebagai dokter dan daun yang ada disekitar rumah dijadikan sebagai obat-obatan. Disekolah guru memfasilitasi anak yaitu SR dan SY sesekali mengikuti pementasan drama baik dalam perlombaan ataupun festival.

\section{Menggambar berbagai macam bentuk yang beragam}

Pada tingkatan ini, SR dan SY sudah bisa menggambar berbagai macam bentuk tetapi terkadang belum bisa melakukan dengan sendirinya dan masih dibantu oleh orangtua/guru di sekolah, terlihat ketika menggambar berbagai bentuk anak telah bisa menggambarnya dengan baik meskipun terlihat belum sempurna. Seperti menggambar bentuk persegi empat, persegi tiga, persegi panjang, lingkaran, dan lain-lain. Meskipun gambar yang dihasilkan oleh SR dan SY belum terlihat sempurna namun mereka sangat senang ditambah hasil gambaran mereka warnai dengan berbagai warna sambil mengatakan kepada ibunya bahwa

6 NANAEKE - Indonesian Journal of Early Childhood Education, Vol. 3, No. 1, Juni 2020 
gambarnya sangat cantik. SR dan SY juga menggambar manusia meskipun terlihat belum sempurna, seperti gambar kepala, badan, tangan dan kaki yang memakai rok.

\section{Melukis dengan berbagai cara dan objek}

Seperti halnya dengan tingkatan sebelumnya, SR dan SY belum bisa secara mandiri melakukan kegiatan menggambar dan melukis. Meskipun demikian dengan bantuan orang tua dan guru SR dan SY bisa melukis dengan menggunakan tangan sebagai bentuk ikan atau finger paint yaitu melukis dengan menggunakan jari serta objek yang lainnya. SY menggambar pengalamannya ketika ke pantai, meskipun gambarnya belum terlalu jelas. SY bercerita bahwa di dalam gambar itu SY bermain pasir. Setelah menggambar/mewarnai, SR dan SY merapikan peralatan menggambarnya masing-masing.

\section{Membuat karya seperti bentuk sesungguhnya dengan berbagai bahan (kertas, plastisin, balok, dIl.)}

Dalam tingkatan ini SR dan SY sudah bisa membuat karya seperti bentuk sesungguhnya, terlihat ketika SR menggunakan kertas untuk membuat topi ulang tahun dan rumah lipat. SY juga membuat karya dari plastisin denga membuat makanan, seperti membentuk mie. SR dan SY sangat berantusias ketika melakukan kegiatan ini, keduanya pun terlihat sangat gembira. Selain pemaparan diatas, SR dan SY juga sangat rapih dalam berpakaian, dan sangat menjaga kebersihannya.

Pada hasil penelitian yang dilakukan peneliti telah menggambarkan bahwa kedua anak (SR dan SY) telah memenuhi capaian perkembangan pada aspek Seni anak berdasarkan standar usia subjek khususnya dalam hal menikmati berbagai alunan lagu atau suara (1. Bersenandung atau bernyanyi sambil mengerjakan sesuatu; 2. Memainkan alat musik/ instrument/ benda bersama teman) dan Tertarik dengan kegiatan seni (1. Menyanyikan lagu dengan sikap yang benar; 2. Menggunakan berbagai macam alat music; 3. Bermain drama sederhana; 4. Menggambar berbagai macam bentuk yang beragam; 5 . Melukis dengan berbagai cara dan objek; 6. Membuat karya seperti bentuk sesungguhnya dengan berbagai bahan). Yang masih belum terpenuhi adalah SR dan SY belum bisa memainkan alat musik tradisional, karena tidak ada yang memfasilitasinya.

Berdasarkan hasil wawancara yang dilakukan kepada kedua orang tua anak, ditemukan bahwa mereka mendidik anak kembar mereka dengan berbagai stumulasi. Adapun upaya yang telah dilakukan orangtua adalah dengan memberikan berbagai stimulus untuk anak, seperti mendukung minat anak dan memperdengarkan anak lagu-lagu yang disukainya. Kemudian orangtua juga memberikan fasilitas berupa beberapa alat permainan yang dapat mengembangkan aspek seni anak begitupun di sekolah anak. Orangtua juga memberikan reward atas keberhasilah anak, seperti jika anak berhasil maka orang 
membelikan anak pensil warna baru, mainan masak-masak sehingga anak tambah semangat. Tidak lupa orang tua responden selalu memberikan pujian dan mengapresiasi setiap hal yang dilakukan anaknya. Kegiatan stimulasi pada anak kembar yang menjadi subjek penelitian ini juga didukung karena adanya kerjasama antara orangtua dan guru disekolah dalam menstimulasi anak.

Perkembangan seni pada anak kembar akan sangat mudah distimulasi jika orangtua dan lingkungan mendukung dan menstimulasi secara seimbang antara anak yang satu dengan anak yang lainnya. Ini membuktikan pada hasil penelitian yang dilakukan peneliti dengan mengambil sampel anak kembar (SR dan SY) bahwa peran orangtua dan lingkungan akan mempengaruhi perkembangan anak khususnya pada perkembangan seni sehingga aspek perkembangan seni dapat terstimulasi dengan baik sesuai dengan standar pencapaian pada perkembangan anak usia dini.

Anak kembar terlahir dengan memiliki banyak persamaan atau kemiripan dari penampilan fisik (Falenttino, 2017). Anak kembar merupakan dua anak individu yang dilahirkan oleh satu ibu secara bersamaan dan memiliki penampilan fisik yang sama. Kelahiran anak kembar dapat terjadi baik secara kembar identik maupun kembar non identik (K. A. Dewi, 2016). Berbeda dengan Syailindri (2018) yang menyatakan bahwa orangtua yang memilik anak kembar seringkali menganggap anak kembar baik yang terlahir identik maupun fraternal sebagai individu yang sama. Sedangkan Agustina (2018) mengatakan bahwa anak kembar mempunyai hubungan emosional yang lebih kuat dibandingkan dengan saudara kandung biasanya, hubungan emosional ini biasanya terjadi karena kembar terbiasa diperlakukan sama oleh lingkungannya, selain karena adanya faktor genetik yang turut serta mempengaruhi kesamaan tersebut. Menurut Altinuari (2018) pada proses tumbuh kembang anak kembar, peran ibu sangat dibutuhkan karena peran ibu sangat mempengaruhi perkembangan anak baik secara fisik, umur, kognitif, bahasa maunpun seni.

Anak kembar merupakan salah satu karakteristik anak yang unik, dimana orangtua harus mengasuh dan memberikan stimulus lebih dari satu anak secara bersamaan dengan tahapan perkembangan yang sama (Lestari, 2016). Anak kembar juga memiliki keunikan tersendiri dalam diri masing-masing, oleh karena itu pendidik maupun orangtua harus menghargai dan menstimulus setiap perkembangan anak mulai dari aspek motorik, sosial, bahasa hingga seni sebagai individu yang memilik kemampuan luar biasa serta karakteristik yang unik dan khas (Rahmat, 2017). Kata "unik" dapat dimaknai bahwa tidak ada manusia yang sama, kondisi manusia tida bersifat tetap, dan setiap tahapan perkembangan manusia mempunyai ciri khusus yang berbeda dengan perkembangan yang lain sehingga untuk dapat memberikan stimulasi dan mengarahkan pembentukan perilaku anak perlu diketahu ciri khusus dari setiap tahapan perkembangan agar dapat menghadapi dan melayani anak secara tepat (Hadi, 2017).

8 NANAEKE - Indonesian Journal of Early Childhood Education, Vol. 3, No. 1, Juni 2020 
Perkembangan anak usia dini memiliki ragam aspek diantaranya, kognitif, fisik motorik, sosial emosional, seni, nilai agama moral dan bahasa. Kemampuan dan intelegensi pada anak kembar memiliki tingkat perbedaan, maka dari itu guru maupun orangtua bisa memahami perbedaan bakat, minat dan potensi yang dimiliki anak dan memberikan stimulasi secara optimal agar semua aspek perkembangan anak kembar dapat berkembang dengan baik (Hasanah, 2019). Anak dilahirkan dengan memiliki minat, bakat, kemampuan dan potensi yang berbeda-beda meskipun anak terlahir kembar namun stimulus yang tepat dan lingkungan sangat berpengaruh dalam mengembangkan berbagai aspek perkembangan anak (Rahayu, 2019). Pertumbuhan dan perkembangan yang dicapai merupakan aktualisasi potensi semua aspek perkembangan anak secara optimal pada setiap tahap perkembangannya. Tingkat pencapaian perkembangan menggambarkan pertumbuhan dan perkembangan yang diharapkan dapat dicapai pada rentan waktu tertentu. Pencapaian perkembangan anak meliputi aspek fisikmotorik, nilai-nilai agama dan moral, kognitif, bahasa, sosial emosional dan seni (Palintan, 2018).

Perkembangan merupakan proses yang tidak pernah berhenti (never ending process) artinya manusia secara terus menerus berkembang dipengaruhi oleh pengalam atau belajar. Semua aspek perkembangan saling memperngaruhi artinya setiap aspek perkembangan individu baik fisik, emosi, intelegensi, seni maupun sosial saling mempengaruhi jika salah satu aspek tersebut tidak ada (Jannah, 2015). Perkembangan anak usia dini merupakan masa yang paling kritis, bukan saja menyangkut pertumbuhan fisik melainkan perkembangan kepribadian pun mulai tampak. Pada fase ini, perkembangan pada aspek seni hendaklah ditanamkan mulai dari pendidikan sekolah dan pendidikan lingkungan ramah, karena ada kecenderungan menganggap pendidikan lain lebih penting dibandingkan pendidikan seni. Perkembangan seni juga dapat mempengaruhi emosi, spiritual dan kebudayaan lebih dari kecerdasan lainnya (Astuti, 2011). Seni merupakan suatu gagasan, ungkapan seseorang yang dituangkan menjadi pola kelakuan khusus sehingga menciptakan karya yang indah, bermakna dalam wujud kesenian berupa pengetahuan, gagasan, dan merupakan nilai-nilai yang ada pada pikiran manusia/kebiasaan.

Pendapat yang sama diungkapkan oleh Ki Hajar Dewantara (Y. Rachmawati, 2005) bahwa "seni merupakan hasil keindahan sehingga dapat mengerakkan perasaan indah orang yang melihatnya. Khususnya untuk anak usia dini yang baru bisa menggambar pemandangan dengan coret-coretan itu dapat dikatakan indah, karena menurut anak apa yang mereka lukiskan dengan menggunakan pensil warna adalah bagus dan menjadi bahagia. Oleh karennya keindahan memiliki makna unik bagi siapa yang menilainya". Sumarjo (Respati, 2015) mengemukakan bahwa mengenal seni dalam berbagai eksistensi yaitu: pertama, seni sebagai ekspresi artinya seni sebagai wujud pengungkapan perasaan seseorang. Kedua, 
seni sebagai benda artinya meskipun seni bukan sekedar benda, namun melalui dimensi "kebendaan" inilah nilai-nilai seni yang ditawarkan kepada penikmatnya. Ketiga, seni sebagai nilai artinya seni memiliki keterkaitan erat dengan nilai daripada sebagai benda. Keempat, seni sebagai pengalam artinya ada pada penikmat seni itu sendiri. Menurut Sumanto (2015) dalam pengalaman edukatif seni dapat: (1) membantu pertumbuhan dan perkembangan anak, (2) seni membantu menyempurnakan kehidupan, (3) seni bermanfaat mengembangkan bakat, dan (4) seni dapat membina perkembangan estertika.

Menurut Pakerti (2010) pendidikan seni pada anak dapat membantu anak untuk mengungkapkan sesuatu yang mereka ketahui dan yang dirasakan sehingga dapat diungkapkan dalam bentuk seni. Pendidikan seni di Indonesia terdapat beberapa macam yakni seni rupa, seni tari, dan seni musik, semua dikembangkan sesuai dengan tahap perkembangan dan aspek-aspek perkembangan anak. Menurut Setiawan (Aprilia, 2014) menyatakan bahwa pendidikan seni juga berperan sangat penting dalam memberikan rangsangan pada bagian otak sebelah kanan (belahan otak) dengan pembelajaran seni juga dapat membuktikan bahwa seni dapat meningkatkan dan menambah wawasan anak juga kepandaian anak dalam berekspresi, meningkatkan pula pemahaman anak perihal sisi-sisi kemanusiaan, serta kepekaan dan kosentrasi yang tinggi terhadap sesuatu.

Pendidikan seni merupakan sesuatu yang berkaitan dengan keindahan hasil karya yang dibuat seseorang. Melalui pengalaman anak yang dapat menuangkan ide serta gagasannya ke dalam hasil karya yang sedang mereka kerjakan. Melalui pendidikan seni secara tidak langsung dapat menjadikan otak kanan dan kiri anak berkembang secara baik. Oleh karena itu, sangat penting memberikan pendidikan seni pada anak agar kreativitas, sensitivitas, fantasi dan ekspresi anak berkembang secara optimal. Hal yang paling utama dalam seni adalah ditemukannya ruang ekspresi diri, artinya seni menjadi wahana seseorang untuk mengungkapkan keinginan, perasaan, pikiran melalui berbagai bentuk aktivitas seni sehingga menimbulkan kesenangan dan kepuasan (Anggraini, 2019).

Antara (2015) juga berpendapat bahwa pendidikan seni dapat memberikan kontribusi kepada perkembangan pribadi anak. Kontribusi yang dimaksud berkaitan dengan pemberian ruang berekspresi, pengembangan potensi kreatif dan imajinatif, peningkatan kepekaan rasa, menumbuhkan rasa percaya diri, dan pengembangan wawasan budaya. Menurut Rukmana (2017) pendidikan seni pada anak merupakan salah satu upaya untuk menggali kemampuan dasar dan potensi anak. Menurut Priyanto (2013) bahwa dalam pendidikan seni, ada beberapa macam kegiatan yang dapat dilakukan di dalamnya yakni: bernyanyi, melalui kegiatan ini dapat berpengaruh terhadap perkembangan bahasa anak, bagaimana dalam berartikulasi yang tepat, kognitif dimana anak dilatih bagaimana ketepatan irama juga kontrol dalam pernapasannya. Menurut Dewi, (2009) dalam dunia pendidikan musik juga mempunyai peran yang begitu penting terutama dalam 
aspek emosi, yaitu dalam mengembangkan dan menambah wawasan anak terhadap perasaan juga dalam berekspresi kreativitas atau daya cipta anak dapat dikembangkan dengan jalan instrument. Dalam hal ini, sebagai alat dalam dunia pendidikan dapat memberikan dampak terhadap emosi juga prestasi yang dimiliki oleh anak.

Perkembangan seni terbagi atas beberapa bidang seni baik yang berhubungan dengan tari, menggambar, melukis dan mewarnai (Zaini, 2017). Perkembangan seni anak menurut Lowenfeld (2007) terbagi atas: “(1) masa coretan bebas, coretan terkontrol, 2-4 tahun pada masa coretan bebas ini anak bebas melakukan coretan-coretan dengan perkembangan motorik tangan dan jarinya menggunakan motorik kasar. Hal ini dapat kita temukan pada anak yang melubangi atau melukai kertas yang di goresnya; (2) masa prabagan 4-7 tahun pada masa ini anak mulai mengggambarkan objek yang berupa gambar kepalaberkaki; (3) masa bagan 7-9 tahun pada masa ini anak mulai menggambar objek apa yang di lihatnya; (4) masa realisme 9-12 tahun pada masa ini karya anak lebih menyerupai kenyataan. Kesadaran persepktif mulai muncul, namun berdasarkan penglihatan sendiri, dan pada pemahaman warna sudah mulai di sadari; (5) masa naturalisme 12-14 tahun pada masa ini kemampuan berfikir abstrak serta kesadaran anak mulai berkembang. Perhatian kepada seni mulai kritis, bahkan terhadap karyanya sendiri; (6) masa penentuan 14-17 tahun pada masa ini tumbuh kesadarann dan kemampuan diri."

Satiadarma (2004) memaparkan bahwa dengan melalui seni terutama musik, selain perkembangan emosi anak yang terpengaruhi dengan melalui musik juga dapat memperbanyak wawasan anak terhadap hidup dan bagaimana anak dalam mengekspresikan dirinya. Dalam lingkungan sekolah musik dapat diciptakan dengan cara sesederhana mungkin, yaitu dengan mendengarkan musik nasional dimana terdapat banyak pelajaran di dalamnya. Hal yang sama di temukan oleh Salahuddin (2019) dari hasil penelitiannya, musik juga digunakan dalam berbagai hal, yaitu sebagai sarana untuk meningkatkan spiritual meskipun banyak perdebatan di dalamnya. Selain itu, dalam hasil temuannya musik banyak digunakan dalam dunia pendidikan, dengan kegiatan seni khususnya musik sangat mempunyai banyak fungsi di dalamnya. Menurut Mursyid (Saputro, 2018) menjelaskan bahwa musik yaitu kegiatan seni dimana mengajarkan cara menyusun nada atau suara dalam larutan menjadi kombinasi sehingga menghasilkan satu kesatuan yang sifatnya berkesinambungan atau dengan kata lain memiliki kandungan/makna irama. Menurut Nasution (2016) musik merupakan salah satu cara untuk melepaskan dan mengekspresikan perasaan, suasana hati dan emosi.

Hal yang sama juga ditemukan oleh Gardner (Rachmi, 2016) dengan teori Multiple Intelligences, teori ini memperkuat pendapat bahwa seni khususnya musik mempunyai fungsi dan berpengaruh dalam mengembangkan intelegensi anak. Teori ini memberikan wacana yang lebih luas dalam memandang seorang anak 
secara holistik. Teori Gardner ini sangat berseberangan dengan teori-teori sebelumnya yang mengatakan bahwa manusia hanya memiliki verballinguistic intelligence dan logical-mathematical intelligence. Menurutnya masih ada enam intelegensia lainnya yang dimiliki oleh setiap manusia yakni musical-rhythmic intelligence, visual-spatial intelligence, bodily-kinesthetic intelligence, interpersonal intelligence, intrapersonal intelligence, dan naturalist intelligence. Gardner menyarankan agar anak belajar dengan kombinasi kedelapan intelegensia yang unik tersebut. Musik dan gerakan diperkaya dengan kombinasi ritmik, melodi, lirik, gerakan, dan kelompok anak yang saling berinteraksi akan menyentuh semua domain". Hirmaningsih (Sihombing, 2013) juga berpendapat bahwa terdapat dua bentuk kegiatan bernyanyi yang dilakukan anak, yang pertama adalah bernyanyi pasif dimana anak hanya mendengar suara nyanyian dan menikmatinya tanpa terlibat secara langsung dalam kegiatan nyanyian dan yang kedua bernyanyi aktif dimana anak melakukan secara langsung kegiatan bernyanyi, baik sendiri, mengikuti, maupun berkelompok. Menurut Tiurma (2012) kegiatan bernyanyi yang sering dilakukan anak usia dini yaitu bernyanyi aktif karena bernyanyi berkaitan dengan ekspresi diri, pengembangan bahasa dan intelektual, hubungan sosial serta kreativitas, dimana semua itu menjadi prinsip dari aspek pengembangan dalam diri anak.

Dalam pengembangan seni diperlukan kreativitas, perkembangan kreativitas diperlukan pada keterampilan bereksplorasi berfikir kreatif dan mengembangkan bakat anak. Anak usia dini menyukai berekplorasi dengan apa yang diinginkan dan bagi anak melakukan kreasi menjadi kesenangan tersendiri bagi mereka. Menurut Pamungkas (2015) dalam seni, setiap orang dinilai memiliki kreativitas dan kecerdasannya masing-masing sehingga seni dapat memfasilitasi setiap anak untuk menuangkan atau mencurahkan segala kreativitas berdasarkan kehendak masing-masing anak. Secara khusus, kerativitas berkarya seni diartikan sebgaai kemampuan menemukan, mencipta, membuat, merancang ulang, dan memadukan suatu gagasan baru maupun lama menjadi kombinasi baru yang divisualkan ke dalam komposisi suatu karya seni dengan didukung kemampuan terampil yang dimilikinya (Rohani, 2017). Kreativitas merupakan suatu proses mental yang dilakukan individu berupa gagasan ataupun produk baru, atau mengkombinasikan antara keduanya yang pada akhirnya akan melekat pada diri anak (Y. Rachmawati, 2005). Sependapat dengan menurut Kurnia (2015) kreativitas merupakan sebagai kemampuan yang berhubungan dengan kelancaran berpikir (fluency), kemampuan untuk mengembangkan, memperkaya, memperinci suatu gagasan (elaboration), keaslian (originality) dan keluwesan (fleksibility).

Menurut Rachmawati dan Kurnia (2010) adapun faktor yang mempengaruhi kreativitas, yaitu: (1) memberikan rangsangan baik pada kepribadiannya serta suasana psikologis (psychological athmosphere). Karena kreativitas anak dapat berkembang jika kepribadian anak terstimulus dengan baik, (2) dapat 
memudahkan anak ketika mengeksplorasi sesuatu yang dilihatnya, yang didengar, yang dipegang, dan apa yang dimainkan anak sebagai bentuk pengembangan kreativitasnya. Karena melalui lingkungan yang kondusif serta mental yang dirangsang, stimulasi kerja dalam otak akan berjalan beriringan, (3) guru pun sangat memegang peranan yang begitu penting terhadap perkembangan kreativitas anak, maksudnya apabila menginginkan sifat yang kreatif pada diri anak, maka diperlukan guru yang memiliki sifat yang kreatif juga sehingga dengan kemampuan yang dimiliki guru dapat tersampaikan ke anak dengan cara pemberian stimulasi yang baik, (4) selain peran guru, yang sangat diperlukan pula yakni partisipasi dan peranan orangtua anak. Pola asuh orang tua sangat berpengaruh dalam pengembangan anak, salah satunya perkembangan kreativitas anak.

Terdapat pendukung perkembangan seni pada anak usia dini, dengan penerapan pembelajaran seni dan kretivitas yang menekankan pada tiga aspek, yaitu: (1) aspek eksplorasi, penngembangan kemampuan bereksplorasi dapat dilakukan dengan memberikan kesempatan kepada anak untuk melakukan beberapa hal seperti; melihat lingkungan dan bagian bagiannya, menggambar objek tertentu berdasarkan observasi yang dilakukannya, dan mengatur tinggi/rendah, lambat, keras/pelan pada vokal pembicaraan atau lagu; (2) ekspresi, pengembangan kemampuan berekspresi dapat dilakukan dengan memberikan kesempatan pada anak untuk melakukan hal-hal seperti mengekspresikan pikiran dan perasaan melalui kegiatan menggambar, bernyanyi lagu sederhana, dan mengeksplorasi jenis gerak tubuh dan ekspresi dengan drama; (3) apresiasi, kemampuan ekspresi pada anak usia dini harus di kembangkan dengan tujuan agar anak dapat menilai dan menghargai pengalaman berkesenian dan karya seni (Huliyah, 2017).

\section{KESIMPULAN}

Berdasarkan hasil penelitian ditemukan keberhasilan anak kembar usia 5 tahun dalam memenuhi Standar Tingkat Pencapaian Perkembangan Anak (STPPA) pada aspek seni, khususnya dalam hal menikmati berbagai alunan lagu atau suara yang dibuktikan dengan kemampuan: (1) bersenandung atau bernyanyi sambil mengerjakan sesuatu; (2) memainkan alat musik/instrument/benda bersama teman. Anak juga telah tertarik dengan kegiatan seni yang dibuktikan dengan kemampuan: (1) menyanyikan lagu dengan sikap yang benar; (2) menggunakan berbagai macam alat musik; (3) bermain drama sederhana; (4) menggambar berbagai macam bentuk yang beragam; (5) melukis dengan berbagai cara dan objek; (6) membuat karya seperti bentuk sesungguhnya dengan berbagai bahan. Keberhasilan tersebut tidak terlepas dari usaha yang telah dilakukan orang tua anak. Adapun upaya yang dilakukan oleh orangtua atau pengasuh dalam memberikan stimulus untuk anak, yakni: (1) mendukung minat anak dan 
memperdengarkan anak lagu-lagu yang disukainya; (2) memberikan apresiasi berbentuk pujian pada anak; (3) memberikan fasilitas berupa beberapa alat permainan yang dapat mengembangkan aspek seni anak; dan (4) apabila anak berhasil melakukan hal positif, maka anak diberikan reward.

\section{DAFTAR PUSTAKA}

Agustina, R. A. (2018). Strategi Komunikasi Twibling Rivalry Anak Kembar Kota Bandung (Studi Deskriptif Mengenai Strategi Komunikasi Twibling Rivalry Anak Kembar dalam Meraih Prestasi). Universitas Komputer Indonesia.

Altinuari, F. (2018). Pengalaman Ibu yang Mengasuh Anak Kembar Identik Sebuah Studi Interpretative Phenomenological Analysis. Universitas Diponegoro.

Anggraini, R. (2019). Analisis Asesmen Perkembangan Seni Gambar Tanpa Wajah Di Taman Kanank-kanak Islam Yogyakarta. Jurnal IImiah Pesona PAUD, 6(2), 94-102.

Antara, P. (2015). Pengembangan Bakat Seni Anak Pada Taman Kanak-Kanak. Jurnal IImiah VISI, 10(1), 29-34.

Aprilia. (2014). Konsepsi Pendidikan Seni Rupa di Taman Kanak-kanak. Semarang:Universitas Gunungpati.

Astuti, F. (2011). Menggali dan Mengembangkan Potensi Kreativitas Seni pada Anak Usia Dini. Jurnal Bahasa Dan Seni, 14(2), 52-63.

Dewi, K. A. (2016). Pola Pengasuhan Orangtua Terhadap Anak Kembar Di Kecamatan Tambakromo Kabupaten Pati. Universitas Negeri Semarang.

Dewi, M. P. (2009). Studi Metaanalisis: Musik Untuk Menurunkan Stres. Jurnal Psikologi, 36(2), 106-115.

Fadillah, M. (2012). Desain Pembelajaran Paud: Tinjauan Teoritik \& Praktik. Jogjakarta: Ar-Ruzz Media.

Falenttino, A. A. S. M. K. dan A. T. S. (2017). Kompetensi Emosi dan Kompetensi Sosial pada Anak Kembar Identik Laki-Laki dengan Gangguan Attention Deficit/Hyperactivity Disorder (ADHD) Sebuah Studi Kasus. Wacana, 9(1), 6682.

Fiah, R. El. (2017). Bimbingan dan Konseling Anak Usia Dini. Jakarta: PT Rajagrafindo Persada.

Hadi, I. A. (2017). Pentingnya Pengenalan Tentang Perbedaan Individu Anak Dalam Efektifitas Pendidikan. INSPIRASI: Jurnal Kajian Dan Penelitian Pendidikan Islam, 1(1), 71-92.

14 NANAEKE - Indonesian Journal of Early Childhood Education, Vol. 3, No. 1, Juni 2020 
Hasanah, A. dan E. M. (2019). Pengaruh Penggunaan Media Diorama terhadap Perkembangan Kemampuan Motorik Halus Anak Usia Dini. Journal on Early Childhood, 2(2), 1-7.

Huliyah, M. (2017). Pengembangan Seni Pada Anak Usia Dini. As-Sibyan: Jurnal Pendidikan Anak Usia Dini, 1(2), 149-164.

Indrijati, H. (2016). Psikologi Perkembangan dan Pendidikan Anak Usia Dini. Jakarta: Kencana.

Jannah, M. (2015). Tugas-Tugas Perkembangan Pada Usia Kanak-kanak. International Journal of Child and Gender Studies, 1(2), 87-98.

Jazuli, M. (2008). Paradigma Kontekstual Pendidikan Seni. Surabaya: Unesa University Press.

Khadijah. (2016). Pengembangan Kognitif Anak Usia Dini. Medan: Perdana Publishing.

Khairi, H. (2018). Karakteristik Perkembangan Anak Usia Dini Dari 0-6 Tahun. Jurnal Warna, 2(2), 15-28.

Khaironi, M. (2017). Pendidikan Moral Pada Anak Usia Dini. Jurnal Golden Age, 1(1), 1-15.

Kurnia, S. D. (2015). Pengaruh Kegiatan Painting dan Keterampilan Motorik Halus Terhadap Kreativitas Anak usia Dini Dalam Seni Lukis. Julnal Pendidikan Usia Dini, 9(2), 285-302.

Kusumastuti, E. (2004). Pendidikan Seni Tari Pada Anak Usia Dini Di Taman Kanakkanak Tadika Puri Cabang Erlangga Semarang Sebagai Proses Alih Budaya. Journal of Arts Research And Education, 5(1).

Lestari, S. dan Y. W. (2016). Gambaran Parenting Stress dan Coping Stress pada Ibu yang Memiliki Anak Kembar. Jurnal Psikogenesis, 4(1), 41-57.

Lowenfeld, V. W. L. B. (2007). Creative and Mental Growth. New York: Macmillan.

Munawaroh, H. (2017). Pengembangan Model Pembelajaran dengan Permainan Tradisional Engklek Sebagai Sarana Stimulasi Perkembangan Anak Usia Dini. Jurnal Obsesi: Jurnal Pendidikan Anak Usia Dini, 1(2), 86-96.

Nasution, R. A. (2016). Pembelajaran Seni Musik Bagi Pengembangan Kognitif Anak Usia Dini. Jurnal Raudhah, 4(1), 11-21.

Nurmalitasari, F. (2015). Perkembangan Sosial Emosi Pada Anak Usia Prasekolah. Buletin Psikologi, 23(2), 103-111.

Pakerti, W. (2010). Metode Pengembangan Seni. Jakarta: Universitas Terbuka.

Palintan, A. T. A. (2018). Penggunaan Media Kolase Dalam Meningkatkan 
Kreativitas Anak. Al-Athfal: Jurnal Pembelajaran Dan Pendidikan Anak Usia Dini, 1(1), 1-9.

Pamungkas, J. (2015). Estetika Koreografi Sebagai Penumpang Kreativitas Seni Anak Usia Dini. Jurnal Pendidikan Anak, 4(1), 596-600.

Priyanto, S. U. (2013). Pendidikan Musik Untuk Anak Usia Dini. Jurnal Pendidikan Sendratasik, 2(1).

Rachmawati, R. K. (2010). Strategi Pengembangan Kreativitas Pada Anak Usia Dini. Jakarta: Kencana Prenada Media Group.

Rachmawati, Y. (2005). Strategi Pengembangan Kreativitas Pada Anak Usia Taman Kanak-kanak. Jakarta: Depdiknas.

Rachmi, T. (2016). Keterampilan Musik dan Tari. Tanggerang Selatan: Universitas Terbuka.

Rahayu, B. T. dan Y. (2019). Pengaruh Kegiatan Bermain Adonan Sabun Terhadap Perkembangan Kreativitas Anak di Raudhatul Athfal 03 Ishlahul Ummah Kota Sawahlunto. Jurnal IImiah Tumbuh Kembang Anak Usia Dini, 4(4).

Rahmat, S. T. dan T. A. S. (2017). Mengembangkan Kreativitas Anak. Jurnal Pendidikan Dan Kebudayaan, 9(2), 95-106.

Respati, R. (2015). Esensi Pendidikan Seni Musik Untuk Anak. Saung Guru, $7(2109-115)$.

Rohani. (2017). Meningkatkan Kreativitas Anak Usia Dini Melalui Media Bahan Bekas. Jurnal Raudhah, 5(2).

Rohendi, H. (2016). Fungsi Pertunjukan Seni Reak Di Desa Cinunuk Kecamatan Cileunik. Jurnal Pendidikan Dan Kajian Seni, 1(1), 54-65.

Rukmana, I. (2017). Pendidikan Seni Sebagai Aspek-Aspek Pembentukan Karakter Pada Anak Usia Dini (Sekolah Berbasis Budaya Loka;). Jurnal Warna, 1(1), 68-77.

Salahuddin. (2019). Mengadopsi Konser Musik dalam Tradisi Tasawuf Ke Dunia Pendidikan Formal. NANAEKE-Indonesia Jurnal Of Early Childhood Education, 2(1), 66-74.

Saputro, F. A. (2018). Perkembangan Seni Anak Usia Dini (STPPA Tidak Tercapai). El-Hamra, 3(3), 55-61.

Satiadarma, M. P. (2004). Cerdas Dengan Musik. Jakarta: Niaga Swadaya.

Satriana, M. (2013). Permainan Tradisional Bebasis Budaya Sunda Sebagai Sarana Stimulasi Perkembangan Anak Usia Anak. Jurnal Pendidikan Usia Dini, 7(1), 65-84.

16 NANAEKE - Indonesian Journal of Early Childhood Education, Vol. 3, No. 1, Juni 2020 
Sihombing, L. B. (2013). Suatu Pendekatan Strategi Dan Metode Pendidikan Seni Melalui Kegiatan Bernyanyi Sebagai Aspek-Aspek Perkembangan Pendidikan Karakter Pada Anak Usia Dini. Generasi Kampus, 6(2).

Sitepu, C. (2020). Tinjauan Gambar Ekspresi Objek Manusia Berdasarkan Teori Lowenfeld Menggunakan Krayon oleh Anak TK B Methodist Berastagi. Universitas Negeri Medan.

Sumanto. (2015). Pengembangan Kreativitas Seni Rupa Anak TK. Jakarta: Depdiknas.

Suryawan, A. (2012). UK Tumbuh Kembang Anak dan Remaja IDAl Jawa Timur: Deteksi Dini Tanda dan Gejala Penyimpangan Pertumbuhan dan Perkembangan Anak. Surabaya: Kencana.

Syailindri, L. dan R. D. (2018). Pengalaman Kemandirian Pada Remaja Kembar Putri: Studi Fenomenologis Dengan Interpretative Phenomenological Analiysis. Jurnal Empati, 7(1), 119-129.

Tiurma, N. (2012). Pendidikan Seni Melalui Kegiatan Bernyanyi Pada Anak Usia Dini. Jurnal Pendidikan Sendratasik, 1(1), 1-14.

Zaini, H. dan K. D. (2017). Pentingnya Media Pembelajaran Untuk Anak Usia Dini. Jurnal Pendidikan Anak Usia Dini, 1(1), 81-96. 